\title{
Hatékony és biztonságos terápia az elhízás gyógyszeres kezelésében: a naltrexon/bupropion kombináció
}

\author{
Hidvégi Tibor dr.
}

\begin{abstract}
Ósszefoglalás
Az elhizás krónikus állapot, amely tartós kezelést igényel a testsúly csökkentése és az elért alacsonyabb súly megtartása érdekében. Az életmódkezelés ideális és biztonságos lehetöség a súlycsökkentésre, az érintettek nagy többsége azonban nem ér el klinikailag jelentös testsúlycsökkenést az étrend megszoritásával és a fizikai aktivitás növelésével. Az életmódkezelés után, vagy az elhizás kezelésére alkalmas gyógyszerek szedését követöen - további beavatkozás nélkül - gyakori a testsúly ismételt növekedése. A naltrexon/bupropion kombináció segiti a testsúly csökkentését és megtartását. Hatását az agy hypothalamicus régiójában fejti ki, amely szabályozza az étvágyat és az energiafelhasználást, ezzel együtt a táplálkozási szokásokat és a ,jutalmazó" funkciókat. Mindez elönyösen érinti az obesitassal együtt járó betegségeket, igy a diabetest és a kardiovaszkuláris kórképeket.

Kulcsszavak: obesitas, naltrexon/bupropion kombináció, étvágy, energiafelhasználás, étkezési szokások, Mysimba $^{\circledR}$

\section{Effective and safe therapy for obesity: naltrexone/bupropion combination}

Summary: Obesity is a chronic condition that requires long-therm treatment to reduce and maintain a lower body weight. Although lifestyle intervention is the ideal and safest way to reduce body weight, most individuals do not achieve clinically meaningful weight loss with diet and exercise alone. Weight regain after lifestyle intervention or cessation of obesity medications is common and patients who stop taking obesity medications will likely experience at least some weight regain without further intervention. The naltrexone/buproprion combination facilitates weight loss and maintenance. The combination acts in hypothalamic brain regions that regulate appetite and energy expenditure, while also influencing eating behavior that is mediated by the reward system, which may yield long-term improvements in obesity related comorbidities such as diabetes and cardiovascular disease.

Keywords: obesity, naltrexone/bupropion combination, appetite, energy consumption, eating habits, Mysimba ${ }^{\circledR}$
\end{abstract}

Rövidítések

AgRP: Agouti-függő peptid (Agouti-related peptide); BMI: testtömegindex (body mass index); BMOD: intenzív viselkedésterápia (behavior modification); CCK: kolecisztokinin; CRH: corticotropin releasing hormone; GLP-1: glukagonszerü peptid-1 (glucagon-like peptide 1); MCH: melanocytastimuláló hormon (melanin concentrating hormone); NB: naltrexon/bupropion kombináció; NCD: járványszerüen terjedő, nem fertőző betegségek (non-communicable diseases); NPY: neuropeptid Y; POMC: pro-opiomelenokortin; PP: pancreaticus polipeptid; PYY: peptid YY; TRH: thyreotropin-releasing hormone 
2 011. szeptember 19-20. között az Egyesült Nemzetek Szervezete állam- és kormányfők jelenlétében rendkívül fontos kérdésről tárgyalt, földünk népességének egészségi állapotáról. A téma a járványszerűen terjedő, nem fertőző betegségek (non-communicable diseases [NCD]) helyzete, térnyerésének lassítása volt, hiszen e feladat már régóta nem csak az egészségügyben dolgozó szakemberek dolga, a döntéshozók, politikusok, kormányok erélyes beavatkozása nélkül nem várható siker. Fontos tény, hogy a 60 év alatti halálozásért négy betegség, a szív-érrendszeri, a daganatos, az idült légzőszervi betegségek, valamint a cukorbetegség a felelős. A közgyűlési határozat az NCD-t mint globális teher és gazdasági fenyegetést mutatja be, amely a XXI. század legjelentősebb egészségügyi kihívása. ${ }^{1}$

Az Európai Unió tagállamaiban 2013-ban több mint 1,2 millióan haltak meg olyan betegségek, sérülések következtében, amelyek megelőzhetők lennének - olvashatjuk az OECD 2016. évi, az Unió polgárainak egészségi állapotáról szóló kiadványában. ${ }^{2}$ Szerteágazó intézkedések szükségesek, hogy a betegségek jelentős részét okozó szív-érrendszeri, daganatos, idült légzőszervi betegségek, valamint a cukorbetegség kockázatának fokozódásához vezető káros életmódi szokások terén komoly változásokat tapasztaljunk. Az Európai Unió aktív életkorú népességéből évente 550000 halálesetet okoznak az életmóddal összefüggő betegségek, ami a lakosság 3,4 millió produktív életévének elvesztését jelenti. Gazdasági téren e veszteség 115 millió eurót jelent, nem említve az egyes emberek és családok felmérhetetlen kárát a családtag korai elvesztése, munkaképtelenné válása miatt.

Kétségtelen, hogy a drámai adatok hátterében a legfontosabb tényező a mozgásszegény életmód, valamint a helytelen táplálkozás és az ezek következtében kialakuló túlsúly, illetve elhízás. Az elhízás prevalenciája világszerte kétszeresére nőtt. ${ }^{3}$ (1980-ban a férfiak 5 , a nők $8 \%$-át érintette, míg 2014-ben a férfiak esetében 11, nők esetében $15 \%$-ra emelkedett). 2014-ben világszerte több mint 1,9 milliárd felnőtt (18 évnél idősebb) személy túlsúlyos és köztük 600 millió elhízott volt. A magyarországi adatok nem biztatóak: ${ }^{4,5,6,7}$ a férfiak $65 \%$-a, a nők $60 \%$-a túlsúlyos vagy elhízott, ezen belül a felnőtt lakosság egynegyede elhízott!

A testsúly csökkentése általában elérhető étrendi megszorítással és a fizikai aktivitás fokozásával, a korábban megszokott életmód mellett a népesség jelentős része egy idő után mégis visszanyeri korábbi testsúlyát. A gyakorlatban jól használható az egészségkockázat megítélésére az 1. táblá$z a t$, ahol a testtömegindex mellett a derékkörfogat mérése is mutatja a kockázat mértékét. A magas testtömegindex és a nagyobb haskörfogat független kockázati tényező az elhízással összefüggő betegségek és kórállapotok tekintetében. E két mérési paramétert mind a Brit Nemzeti Egészségügyi Intézet (NICE), mind az Egészségügyi Világszervezet (WHO) együttesen ajánlja a kockázat megítélésére. ${ }^{9,10}$

Anderson és munkatársai metaanalízisének eredményei ${ }^{11}$ azt mutatják, hogy diéta és fizikai aktivitás, vagy diéta alkalmazása után 4,5 évvel az átlagos testsúlycsökkenés $3 \mathrm{~kg}$ volt, ami a kiindulási súly 3,2\%-át reprezentálja. A Wing és Hill által javasolt definíció ${ }^{12}$ szerint a sikeres súlycsökkentés azt jelenti, ha valaki a testsúlya 10\%-át elveszíti, és azt legalább egy évig megtartja. A táplálkozás, fizikai aktivitás naponkénti jelentős variabilitása ellenére a testsúly hosszabb távon általában stabil marad.

\section{1. táblázat. Egészségkockázat: a testtömegindex és derékkörfogat összefüggése ${ }^{8}$}

\begin{tabular}{|c|c|c|c|c|}
\hline \multirow{2}{*}{\multicolumn{2}{|c|}{ BMI $\left(\mathrm{kg} / \mathrm{m}^{2}\right)$}} & \multicolumn{3}{|c|}{ Derékkörfogat (cm) } \\
\hline & & \multirow{2}{*}{$\begin{array}{c}\text { Normális } \\
\text { férfi: }<94 \text { / nő: }<80 \\
\text { nem alkalmazandó }\end{array}$} & \multirow{2}{*}{$\begin{array}{c}\text { Nagy } \\
\text { férfi: 94-102 / nő: 80-88 } \\
\text { nem alkalmazandó }\end{array}$} & \multirow{2}{*}{$\begin{array}{c}\text { Igen nagy } \\
\text { férfi: > } 102 \text { / nö: > } 88 \\
\text { nem alkalmazandó }\end{array}$} \\
\hline Alultánláltsáa & $<185$ & & & \\
\hline Egészséges testsúly & $18,5-24,9$ & nincs fokozott kockázat & nincs fokozott kockázat & nincs fokozott kockázat \\
\hline Túlsúly & $25-29,9$ & nincs fokozott kockázat & fokozott kockázat & nagy kockázat \\
\hline Elhízás & $30-39,9$ & fokozott kockázat & nagy kockázat & nagyon nagy kockázat \\
\hline Morbid obesitas & $\geq 40$ & nagyon nagy kockázat & nagyon nagy kockázat & nagyon nagy kockázat \\
\hline
\end{tabular}




\section{A testsúly homeostasisa}

A homeostasis szabályozása ${ }^{13}$ elsősorban a hypothalamusban történik a perifériáról beérkezett rövid és hosszabb távú információk segítségével. A legfontosabb régió a táplálkozás szabályozásában a hypothalamus nucleus arcuatusa. Az itt lévő neuronok neuropeptid Y (NPY) és Agouti-függő peptid (AgRP) expressziója útján stimulálják a táplálékfelvételt, míg a pro-opiomelenokortin (POMC) ezzel ellentétes hatású. A nucleus arcuatusból más hypothalamicus régiókba (pl. a nucleus paraventricularisba) irányulnak pályák, ahol a TRH-, CRH-, illetve oxitocintermelődés eredményeként étvágycsökkentő, míg a laterális hypothalamusban a melanocytastimuláló hormon $(\mathrm{MCH})$ és az orexin hatására étvágyfokozó hatás jön létre. A perifériáról beérkező jelek természetesen befolyásolják a hypothalamicus terület funkcióját. A zsírszövetből származó leptin, a pacreasinzulin termelése inkább az energiaegyensúly hosszabb távú, míg a tápcsatornából érkezett jelek - ghrelin, kolecisztokinin (CCK), glukagonszerü peptid (GLP)1, amilin, pancreaticus polipeptid (PP), PYY - rövid távú (étkezéstől étkezésig tartó) információt és szabályozást tesznek lehetővé. Az információk a véráram és a nervus vagus útján kerülnek a hypothalamusba (2. táblázat). Az információ áramlása természetesen ellentétes irányban is biztosítja a szervek és végső soron az energia és testsúly homeostasisát. Az egyensúlyt biztosító élettani mechanizmusok mellett a hypothalamus stimulációt kap a cortextől és a limbicus rendszertől is, ezeket „hedonikus” ingereknek nevezzük. Az ételek látványa, illata, íze, a táplálkozással összefüggő szociokulturális hatások jelentős szerepet játszanak és felülírják a fiziológiás rendszer működését. Az étvágyszabályozás hedonikus és élettani regulációjának egyes elemei pontosan ismertek. Például a leptin befolyásolja táplálkozásunkban az ízlést és a ,jutalmazó”, funkciókat, a ghrelin a mesolimbicus dopaminerg receptorok útján az édes ételek fogyasztását. A kannabinoid receptorok a hypothalamicus magokban fontos szerepet játszanak az étvágy szabályozásában, stimulálásuk nemcsak a táplálékbevitelt, hanem az ízletes ételek fogyasztásának növekedését is eredményezi.

\section{A naltrexon és bupropion kombináció hatása az energiaegyensúlyra}

Hazánkban az elhízás kezelésére engedélyezett vényköteles gyógyszerkészítmények közül az orlistat - Xenical ${ }^{\circledR}$ - és a naltrexon/bupropion kombináció $\left(\mathrm{Mysimba}^{\circledR}\right)$ áll rendelkezésre. A naltrexon opioidantagonista, korábban sikeresen alkalmazták idült alkoholisták és opioidkészítmények iránti függőség kezelésére.

\begin{abstract}
A hypothalamicus melenokortin és az ún. ,jutalmazó” rendszer opioidneuronokat tartalmaz, így a naltrexon adása mellett az ízletes ételek utáni vágy csökken, ez a hatás független a mellékhatásoktól (hányinger). Csökken a táplálékbevitel mennyisége, a testsúly. A kedvező klinikai vizsgálatok ellenére a szer monoterápiában jelentős súlycsökkentést nem eredményezett.
\end{abstract}

A bupropion az atípusos antidepresszánsok csoportjába tartozó készítmény, sikeresen alkalmazták a dohányzás iránti vágy csökkentésére, depresszióban és affektív viselkedési zavarok esetén. A szer gátolja az adrenalin, noradrenalin felvételét a szinapszisokon, és emellett enyhe acetil-

\section{2. táblázat. Az étvágy szabályozásában részt vevő fehérjék és hormonok}

\begin{tabular}{|c|c|c|}
\hline Hely & Anorexigén & Orexigén \\
\hline \multicolumn{3}{|l|}{ Centrális } \\
\hline Hypothalamus & $\begin{array}{l}\text { POMC, nesfatin, TRH, CRH, oxitocin, szerotonin, } \\
\text { hisztamin, urokortin }\end{array}$ & $\begin{array}{l}\text { NPY, AgRP orexin, MCH, endokannabionidok, } \\
\text { opioidok }\end{array}$ \\
\hline \multicolumn{3}{|l|}{ Perifériás } \\
\hline Gastrointestinalis tractus & $\begin{array}{l}\text { CCK, GLP-1, PYY, oxintomodulin, enterosztatin, } \\
\text { bombezin, uroguanilin }\end{array}$ & ghrelin \\
\hline Pancreas & amilin, inzulin, PP & \\
\hline Adipocyta & leptin & \\
\hline
\end{tabular}


kolingátló hatással is rendelkezik. A melenokortinrendszert a dopamin- és a noradrenalinhatás jelentősen befolyásolja, obesitas esetén a hypothalamus dopaminerg tónusa alacsony szintű. A bupropion ideális terápiás lehetőség a hypothalamicus melenokortinrendszer befolyásolására.

A pro-opimelenokortin sejtek aktivitását a bupropion in vitro vizsgálatok során növelte. Az ismert antidepresszáns és hatékony nikotin iránti vágy csökkentő hatás alapján nyilvánvaló a ,jutalmazó” funkcióra gyakorolt hatása. A naltrexon és bupropion kombinációval kapcsolatos II. fázisú klinikai vizsgálatok során a naltrexon/bupropion kombináció (NB) hatását elhízott személyek kezelésével hasonlították össze naltrexon-, vagy bupropion-monoterápia és placebo adásával 24 és 48 hetes megfigyelés eredményeivel. ${ }^{14,15}$

Az NB kombinációval kezelt személyek esetében nagyobb súlycsökkentést lehetett elérni, mint az a két készítmény együttes hatásától várható lett volna. Az egyik III. fázisú, dóziskereső vizsgálat ${ }^{13}$ azt mutatta, hogy az NB csoportban kétszer nagyobb testsúlyredukció volt elérhető, mint a bupropionmonoterápiás csoportban. A visceralis zsírszövet mennyisége is csökkent a teljes testzsír mennyisége mellett.

Az alábbi vizsgálat ${ }^{16}$ igazolta az NB kombináció hatékonyságát és biztonságosságát. 1742, mindkét nembeli, 18-65 év közötti életkorú személyt vontak be egy 56 hétig tartó vizsgálatba. A résztvevők testtömegindexe $30-45 \mathrm{~kg} / \mathrm{m}^{2}$ közötti (szövődménymentes obesitas), illetve $27-45 \mathrm{~kg} / \mathrm{m}^{2}$ közötti (dylipidaemiával, hypertoniával kombinált túlsúly/elhízás) volt. A kettős vak, placebokontrollos, III. fázisú vizsgálatot 34 amerikai centrumban végezték, 1:1:1 randomizáció mellett, amikor az egyik csoport napi $32 \mathrm{mg}$ naltrexont és $360 \mathrm{mg}$ bupropiont, a másik $16 \mathrm{mg}$ naltrexont és $360 \mathrm{mg}$ bupropiont, a harmadik napi 2 alkalommal placebót kapott fix dózisú tablettában. A betegek alacsony kalóriatartalmú étrenden voltak, és napi rendszerességű fizikai aktivitást folytattak. Az öszszetett elsődleges végpont a testsúlycsökkenés százalékos aránya, valamint a legalább 5\%-os, vagy ennél nagyobb súlycsökkenést elérő személyek aránya. Eredmények: a testsúly átlagos csökkenése $-1,3 \%$ a placebocsoportban, $-6,1 \%$ a $32 \mathrm{mg}$ naltrexont és $360 \mathrm{mg}$ bupropiont kapott személyeknél ( $\mathrm{p}<0,0001$ vs. placebo), valamint $-5,0 \%$ a $16 \mathrm{mg}$ naltrexon és $360 \mathrm{mg}$ bupropion kezelésnél ( $\mathrm{p}<0,0001$ vs. placebo). A placebocsoportban 84 fónél $(16 \%)$ csökkent a testsúly legalább 5\%-kal, míg $32 \mathrm{mg}$ naltrexon és $360 \mathrm{mg}$ bupropion kezelés esetén 226 személy (48\%) esetében ( $\mathrm{p}<0,0001$ vs. placebo). Ugyanez a $16 \mathrm{mg}$ naltrexont és $360 \mathrm{mg}$ bupropiont kapó csoportban 186 fő (39\%) esetében igazolódott. Mellékhatásként fejfájás, szédülés, hányás, szájszárazság a gyógyszeres csoportban gyakrabban fordult elő. A systoles és diastolés vérnyomás 1,5 Hgmm-es átmeneti emelkedése ugyancsak a gyógyszerrel kezelteknél fordult elő. Depresszív tünet, suicid késztetés nem fordult elő.

Egy további kettős vak, placebokontrollos vizsgálatban ${ }^{17} 1496$ elhízott (BMI 30-45 kg/m²), illetve hypertoniás, dyslipidaemiás obes (BMI 27-45 $\mathrm{kg} / \mathrm{m}^{2}$ ) személyt randomizáltak 2:1 arányban. Az aktív ágon napi $32 \mathrm{mg}$ naltrexont és $360 \mathrm{mg}$ bupropiont alkalmaztak, a fele létszámú kontrollcsoportban placebót adtak az 56 hetes kezelés során. $\mathrm{Az}$ adatok értékelése a testsúly százalékos változása és a 28 . héten $\geq 5 \%$-os súlycsökkenést elért személyek aránya alapján történt. Az 56 hetes követés után placebóval való összehasonlításban nagyobb testsúlycsökkenést észleltek a 28 . héten $(-6,5 \%$ vs. $-1,2 \%, \mathrm{p}<0,001)$. A gyógyszer-kombinációval végzett kezelés esetén értek el nagyobb arányban $\geq 5 \%$ súlycsökkenést $(55,6 \%$ vs. $17,5 \%$, $\mathrm{p}<0,001)$. A jelentős különbség az 56. hét végén is megmaradt (50,5\% vs. 17,1\%). Ezzel párhuzamosan javultak a kardiometabolikus paraméterek és az életminőség is. A kezelt csoportban a leggyakoribb mellékhatás az átmeneti jellegü hányinger volt. Vizsgálták a depresszióra való hajlamot és suicid késztetést is, a placebóval történt összehasonlítás alapján azonban nem észleltek gyakoribb előfordulást.

A testsúly csökkentésére irányuló lehetőségek között az orvosi táplálkozásterápia, a fizikai aktivitás fokozása mellett a viselkedés megváltoztatására irányuló kezelés is fontos eszköz lehet. Egy klinikai vizsgálatban ${ }^{18} 793$ személy (BMI: $36,5 \pm 4,2$ $\mathrm{kg} / \mathrm{m}^{2}$ ) 1:3 arányú randomizációjában placebo + intenzív viselkedésterápia (Behavior Modification [BMOD]), illetve naltrexon $32 \mathrm{mg} / \mathrm{nap}+$ bupropion $360 \mathrm{mg} / \mathrm{nap}$ + BMOD kezelést alkalmaztak 56 hetes követés során. Placebo + BMOD terápia mellett a vizsgálat végén a súlycsökkenés $5,1 \pm 0,6 \%$, míg a gyógyszer-kombináció + BMOD 
esetén $9,3 \pm 0,4 \mathrm{~kg} / \mathrm{m}^{2}(\mathrm{p}<0,001)$ volt. A kezdeti testsúly 5 és $10 \%$-os csökkenése a gyógyszeres és BMOD kombinációval kezelt csoportban alakult előnyösebben. A szerzők a kedvező tapasztalatok miatt BMOD kezelés kiegészítésére is ajánlják a naltrexon/bupropion terápiát.

Egy 56 hétig tartó, túlsúlyos/elhízott, 2-es típusú diabeteses személyeken végzett placebokontrollos, kettős vak vizsgálat során a naltrexon/bupropion (NB) kezelés hatékonyságát és biztonságosságát elemezték. ${ }^{19} 505$ személy 2:1 arányú randomizálásakor standard életmód-terápia mellé NB- vagy placebokezelést alkalmaztak. Az összetett elsődleges végpontok a testsúly százalékos csökkenése és a $\geq 5 \%$ súlycsökkenést mutató személyek aránya, a másodlagos végpontok a $\mathrm{HbA}_{1 \mathrm{c}}<7,0 \%$ és a $\geq 10 \%$ súlycsökkenést elérő személyek megoszlása, valamint a haskörfogat, az éhomi vércukorszint és a lipidparaméterek terén kialakult változások voltak.

Kiindulási paraméterek: $80 \%$ kaukázusi rasszhoz tartozó, $54 \%$ nő, átlagos életkor 54 év, testsúly 106 kg, BMI 37,0 $\mathrm{kg} / \mathrm{m}^{2} \mathrm{HbA}_{1 \mathrm{c}} 8,0 \%$. Az NB-terápia szignifikáns mértékű súlycsökkenéssel járt $(-5,0$ vs. $-1,8 \%, \mathrm{p}<0,001)$, a $\geq 5 \%$ súlycsökkenést mutató személyek aránya is nagyobb volt (44,5 vs. $18,9 \%, \mathrm{p}<0,001)$. Az NB-kezelés mellett javult a $\mathrm{HbA}_{1 \mathrm{c}}$-érték ( $-0,6 \%$ vs. $-0,1 \%, \mathrm{p}<0,001)$, a $\mathrm{HbA}_{1 \mathrm{c}}<7,0 \%$-ot elérők aránya $(44,1$ vs. $26,3 \%, \mathrm{p}<0,001)$. A koleszterin- és trigliceridértékek is javulást mutattak. NB-terápia mellett a hányinger, székrekedés, gyakrabban fordult elő. Placebóval összehasonlítva a depresszióra való hajlam és a suicid késztetés, valamint a hypoglykaemia gyakoribb előfordulását nem észlelték.

A Mysimba ${ }^{\circledR}$ gyógyszerkészítmény terápiás javallatai és alkalmazása vonatkozásában utalunk a hivatalos gyógyszer-előiratra. A Mysimba ${ }^{\circledR}$ retard tabletta $8 \mathrm{mg}$ naltrexon-hidrokloridot - ami 7,2 mg naltrexonnak felel meg -, valamint $90 \mathrm{mg}$ bupropion-hidrokloridot tartalmaz, ez utóbbi $78 \mathrm{mg}$ bupropionnal egyenértékủ. Felnőtt ( $\geq 18$ éves) betegek csökkentett kalóriatartalmú étrendjének és fokozott fizikai aktivitásának kiegészítéseként, a testtömeg csökkentésére javallott, amennyiben a kiindulási testtömegindex $(\mathrm{BMI}) \geq 30 \mathrm{~kg} / \mathrm{m}^{2}$ (elhízás), vagy $\geq 27 \mathrm{~kg} / \mathrm{m}^{2}-<30 \mathrm{~kg} / \mathrm{m}^{2}$ közötti és a túlsúlyossággal, illetve a testtömeggel összefüggő társbetegségek (pl. 2-es típusú diabetes, dyslipidaemia vagy beállított hypertonia) közül egy vagy több is fennáll. Az adagolást a 3. táblázatban foglaltak szerint kell beállítani.

A Mysimba ${ }^{\circledR}$ ajánlott maximális napi adagja kétszer két tabletta, az alkalmazásával folytatott kezelést 16 hét elteltével le kell állítani, ha a beteg kezdeti testtömege nem csökkent legalább 5\%-kal. A készítmény fontosabb ellenjavallatait a 4. táblázat tartalmazza. A gyógyszer vényköteles, jelenleg társadalombiztosítási támogatásban nem részesül.

Az elhízás járványszerű terjedése szoros összefüggést mutat a 2-es típusú cukorbetegség, a szívés érrendszeri kórképek, légzőszervi és daganatos betegségek, mozgásszervi panaszok megjelenésével/fokozódásával és az életminőség jelentős romlásával. A terápia, a relapszus megelőzése nehéz, és élethosszig tartó feladat. ${ }^{20} \mathrm{~A}$ gyakorló orvost az

3. táblázat. A Mysimba adagolása: a dózist 4 héten keresztül emelni kell

\begin{tabular}{|c|c|c|}
\hline \multirow{2}{*}{ Időpont } & \multicolumn{2}{|c|}{ Adagolás (db tabletta) } \\
\cline { 2 - 3 } & Reggel & Este \\
\hline 1. héten & 1 & \\
\hline 2. héten & 1 & 1 \\
\hline 3. héten & 2 & 1 \\
\hline 4. héten és azt követően & 2 & 2 \\
\hline
\end{tabular}

\section{4. táblázat. A Mysimba ${ }^{\oplus}$ föbb ellenjavallatai}

- A készítmény hatóanyagá(ai)val, bármely segédanyagával szembeni túlérzékenység

- Kezeletlen hypertoniás betegek

- Aktuálisan fennálló vagy a kórtörténetben szereplő epilepszia esetén

- Ismert központi idegrendszeri tumoros betegek

- Alkohol vagy benzodiazepinek hirtelen megvonását követő stádiumban lévő betegek

- Betegek, akik kórtörténetében bipoláris zavar szerepel

- Bupropiont vagy naltrexont tartalmazó bármiféle gyógyszert egyidejüleg szedő betegek

- Aktuálisan idült opioid-,vagy opiátagonista-függő, illetve akut opiátmegvonás állapotában lévő betegek

- Olyan betegek, akiknél aktuálisan vagy előzőleg bulimiát vagy anorexia nervosát állapítottak meg

- Monoaminooxidáz-gátlókat (MAOI) egyidejűleg szedő betegek: MAOI abbahagyása és a naltrexonnal/bupropionnal végzett kezelés megkezdése között legalább 14 napnak kell eltelnie - Súlyos májkárosodástól szenvedő betegek

- Végstádiumú veseelégtelenség vagy súlyos vesekárosodás esetén 
5. táblázat. Az obesitas fokozatai és kezelése klinikai és funkcionális jelek alapján

\begin{tabular}{|c|c|c|}
\hline $\begin{array}{c}\text { Az elhízás } \\
\text { foka }\end{array}$ & Jellemzői & Kezelés \\
\hline 0 & $\begin{array}{l}\text { Nincsen obesitassal összefüggő kockázati tényező (pl. magas vérnyomás, } \\
\text { kóros lipidértékek, emelkedett éhomi vércukorérték), nincsenek fizikális } \\
\text { tünetek, a fizikai aktivitás nem korlátozott / a közérzet jó }\end{array}$ & $\begin{array}{l}\text { Tanácsadás. A túlsúllyal/elhízással kapcsolatos } \\
\text { tényezők felkutatása, a további súlynövekedés } \\
\text { megakadályozása életmódterápiával (helyes } \\
\text { táplálkozás és a fizikai aktivitás fokozása) }\end{array}$ \\
\hline 1 & $\begin{array}{c}\text { Az elhízással összefüggésben álló szubklinikus kockázati tényezők (pl. } \\
\text { határérték-hypertonia, emelkedett éhomi vércukorszint, emelkedett } \\
\text { transzamináz-értékek stb.) enyhe fizikális jelek, nehézlégzés mérsékelt } \\
\text { fizikai aktivitás esetén, fáradtság, ízületi fájdalmak, időnként rosszabb } \\
\text { közérzet }\end{array}$ & $\begin{array}{l}\text { Vizsgálat. A testsúllyal nem összefüggő kockázati } \\
\text { tényezők keresése. Az életmódkezelés további } \\
\text { erősítése (helyes táplálkozás és a fizikai aktivitás } \\
\text { fokozása) A kockázati tényezók és az egészségi } \\
\text { állapot folyamatos követése }\end{array}$ \\
\hline 2 & $\begin{array}{l}\text { Az elhízással kapcsolatos idült betegségek megjelenése (hypertonia, } \\
\text { 2-es típusú cukorbetegség, alvási apnoe szindróma, idült mozgásszervi } \\
\text { degeneratív betegségek, refluxbetegség, polycystás ovárium szindróma, } \\
\text { szorongás). A mindennapi fizikai aktivitás mérsékelten korlátozott/romló } \\
\text { közérzet }\end{array}$ & $\begin{array}{l}\text { Az obesitas kezelése (viselkedésterápia, } \\
\text { gyógyszeres, sebészi terápia) a társbetegségek } \\
\text { szoros követése és kezelése. }\end{array}$ \\
\hline 3 & $\begin{array}{c}\text { Szervkárosodások megjelenése, pl. myocardialis infarctus, szívelégtelenség, } \\
\text { a cukorbetegség idült szövődményei, jelentős fizikai és pszichés } \\
\text { állapotromlás és rossz közérzet }\end{array}$ & $\begin{array}{l}\text { Az obesitas és társbetegségek szoros követése } \\
\text { és agresszív kezelése (viselkedésterápia, } \\
\text { gyógyszeres, sebészi terápia) }\end{array}$ \\
\hline 4 & $\begin{array}{l}\text { Obesitassal összefüggő rokkantság (végállapot), az idült betegségek súlyos } \\
\text { formái, súlyos pszichés károsodás kialakulása, a mindennapi életvitel } \\
\text { jelentősen korlátozott, kifejezetten rossz közérzet }\end{array}$ & $\begin{array}{l}\text { A lehetséges és megoldható agresszív kezelés, } \\
\text { fájdalomcsillapítás, folyamatos pszichés } \\
\text { támogatás }\end{array}$ \\
\hline
\end{tabular}

obesitas terápiájának megválasztásában segítheti az 5. táblázat.

A dietoterápia, mozgásterápia és pszichoszomatikus kezelés mellett egyre gyakoribb a morbid elhízás kezelésében a bariátriai sebészet módszereinek alkalmazása. Obes/túlsúlyos betegeink kezelése során a natrexon/bupropion gyógyszerkombináció a komplex kezelés tagjaként hatékony segítség lehet.

\section{Köszönetnyilvánítás}

A cikk megjelenését a Valeant Pharma Magyarország Kft. támogatta.

A cikk tartalma a szerző eredményeit és önálló szakmai álláspontját tükrözi, és nem tekinthető a Valeant Pharma Magyarország Kft. szakmai vagy egyéb tájékoztatásának vagy állásfoglalásának. A megemlített termékek használatakor az érvényes alkalmazási előírás az irányadó. 


\section{rrodalom}

1. United Nations Resolution adopted by the General Assembly on 19 September 2011. 66/2. Political Declaration of the High-level Meeting of the General Assembly on the Prevention and Control of Non-communicable Diseases. www.who.int/nmh/events/un_nd_summit2011/en/

2. OECD/Eu (2016), Health at a Glance: Europe 2016. State of health in the EU cycle OECD Publishing, Paris. www.oecd-ilibrary.org/health-at-a-glanceeurope-2016_5j|r3c140n9q.pdf

3. World Health Organization. The European health report 2015, Targets and beyond - reaching new frontiers in evidence. WHO Geneva, 2015. www. euro.who.int/en/data-and-evidence/european-health-report/europeanhealth-report-2015/ehr2015

4. Pados Gy, Simonyi G, Bedros JR: Uj lehetőség az elhizás gyógyszeres kezelésére: a naltrexon-bupropion kombináció. Metabolizmus 2016; 5 : 360-364.

5. Pados Gy, Simonyi G, Audikovszky M, Bedros JR: Ujjdonságok az elhizás diétás és gyógyszeres kezelésében. Metabolizmus 2017; 2: 122-126.

6. Rurik I, Ungvári T, Szidor J, Torzsa P, Móczár CS, Jancsó Z, et al.: Elhizó Magyarország. A túlsúly és elhizás trendje és prevalenciája Magyarországon, 2015. Orv Hetil 2016; 157(31):1248-1255.

7. Martos É, Kovács VA, Bakacs M, Kaposvári C, Lugasi A: Országos Táplálkozás és Tápláltsági Állapot Vizsgálat - OTÁP 2009. Orv Hetil 2012; 153(26): 1023-1030.

8. Sharma AM, Kushner RF: A proposed clinical staging system for obesity. Int J Obes 2009; 33: 289-295. doi:10.1038/ijo.2009.2

9. Health Survey for England (HSE) Annual report and accounts 2016 to 2017 www.hscic.gov.uk/healthsurveyengland

10. National Institute for Health and Care Excellence. Obesity: identification, assessment and management. London, 2014. (Accessed on 28 July 2016) https://www.ncbi.nlm.nih.gov/books/NBK11822/

11. Anderson JV, Koncz EC, Frederich RC, Wood CL: Long term weight-loss maintenance: a meta analysis of US studies. Am J Nutr 2001; 74(5): 579-584.

12. Wing RR, Hill J0: Successful weight loss maintenance. Annu Rev Nutr 2001; 21: 323-341. doi:10.1146/annurev.nutr.21.1.323

13. Sumithran P, Proiretto J: The defence of body weight: physiological basis for weight regain after weight loss. Clinical Science 2013; 124(4): 231-241. doi:10.1042/CS20120223

14. Greenway FL, Dunayevich E, Tollefson G, Erickson I, Guttadauria M, Fujioka K, et al.: Comparison of combined bupropion and naltrexone therapy for obesity with mono-therapy and placebo. I Clin Endocrinol Metab 2009; 94(12): 4898-4906. doi:10.1210/j. $2009-1350$
15. Greenway FL, Whitehouse MJ, Guttadauria M, Anderson JW, Atkinson RL, Fujioka $\mathrm{K}$ et al: Rational design of a combination medication for the treatment of Obesity. Obesity (Silver Spring) 2009; 17(1): 30-39. doi:10.1038/oby.2008.461

16. Smith SR, Fujioka K, Gupta AK, Billes SK, Burns C, Kim D, et al: Combination therapy with naltrexone and bupropion for obesity reduces total and visceral adiposity. Diabetes Obes Metab 2013; 15(9): 863-866. doi:10.1111/dom.12095

17. Greenway FL, Fujioka K, Raymond A. Plodkowski, Sunder Mudaliar, et al: Effect of naltrexone plus bupropion on weight loss in overweight and obese adults (COR-1.): a multicentre, randomised, double blind, placebo controlled, phase 3 trial. Lancet 2010; 376(9741): 595-605. doi:10.1016/50140-6736(10)60888-4

18. Apovian CM, Aronne L, Rubio D, Still C, Wyatt H, Burns C, et al:. A randomized, phase 3 trial of naltrexone SR/bupropion SR on weight and obesityrelated risk factors (COR-II.) Obesity (Silver Spring) 2013; 21(5): 935-943. doi:10.1002/0by.20309

19. Wadden TA, Foreyt JP, Foster GD, Hill JO, Klein S, O'Neil PM, et al: Weight loss with naltrexone SR/buproprion SR combination therapy as an adjunct to behavior modification: The COR-BMOD Trial. Obesity (Silver Spring) 2011; 19(1): 110-120. doi:10.1038/oby.2010.147

20. Hollander P, Gupta AK, Plodkowski R, Greenway F, Bays H, Burns C, et al: Effects of naltrexone sustained-release/bupropion sustained-release combination therapy on body weight and glycemic parameters in overweight and obese patients with type 2 diabetes. Diabetes Care 2013; 36(12): 4022-4029. doi:10.2337/dc13-0234

Közlésre érkezett: 2017. október 26.

Közlésre elfogadva: 2017 . november 2 .

\section{A szerzö levelezési címe:}

\section{Dr. Hidvégi Tibor}

Petz Aladár Megyei Oktató Kórház

9024 Györ, Vasvári Pál u. 2-4.

E-mail: hidvegi@t-online.hu 